\title{
MARITIME LAW
}

\section{МОРСЬКЕ ПРАВО}

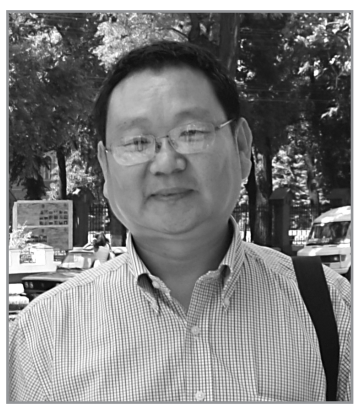

\author{
Zhang Shuibao* \\ $\mathrm{PhD}$ in Law, Beijing Allied Law Offices \\ (Beijing, China) \\ https://orcid.org/0000-0003-3799-5067
}

*Zhang Shuibao, PhD in Law, Beijing Allied Law Offices (Room 2603-2606 Xintiandi B Xibahenanlu jia 1, District Chaoyang Beijing 100028, Beijing, China).

\section{REGISTRATION OF VESSELS IN THE PRC: DIVERSITY OF LEGAL REGIMES}

\section{РЕССТРАЦІЯ МОРСЬКИХ СУДЕН У КНР: РІЗНОМАНІТТЯ ПРАВОВИХ РЕЖИМІВ}

\section{ABSTRACT}

The article is focused on determining the mechanism for the registration of maritime vessels in the PRC. The basis of the study is the international legal framework for the registration of vessels - the United Nations Convention on the Law of the Sea 1982 and the Convention on Conditions for Registration of Ships, 1986. The legislation of mainland China and the special administrative regions of Hong Kong and Macau is considered. The procedures that are applied for entering vessels in their state registers are defined. Positive and negative tendencies of development of registration mechanisms and innovations implemented are outlined. A number of general scientific and specific legal methods were applied 
during the study. They allowed to develop the author's vision of possible and desirable changes in the organizational and legal mechanism of registration of vessels in China. The author concludes that there are differences in the procedures for registering ships in mainland China and in special administrative districts. This is a consequence of the prevailing legal tradition in these territories of the western and somewhat more democratic than in mainland China. It is also facilitated by the right to self-identify and regulate most areas of domestic policy, which include shipping. Thus the ship registration rules in PRC can be viewed as three parallel legal orders, that include the Mainland China, the Free Trade Zones and the Hong Kong Special Administrative Region.

The key words: ship registration, international shipping, shipping policy, China, Hong Kong Special Administrative Region of the People's Republic of China, Macao Special Administrative Region of the People's Republic of China.

\section{Introduction}

The development of the world merchant fleet is the result of the dynamics of the international trade and international shipping. The PRC is currently one of the key players in the world maritime business. Due to the sufficiently stringent rules of registration between vessels and the state, there is a reliable real connection - one of the main requirements of the 1982 UN Convention on the Law of the Sea. Every year, the number of registered vessels is increasing not only in the PRC, but worldwide. China's Maritime Merchant Navy, competing with the Greek and Japanese in quantity, is ranked second in 2018 (China-owned fleet becomes world's second largest) and third in 2019 (Deadweight tonnage of world merchant fleets by operator domicile as of January 1, 2019) in the world. However, the replenishment of the modern merchant fleet is characterized by a certain inertia: the ordered vessels continue to be built and enter the market although the demand for them has already weakened, and new buildings only create problems of excess tonnage. At the same time, on the other hand: improving fleets, reducing freight costs open up new opportunities for trade, and include in trade turnover the regions and goods for which high cost of transport has previously been a serious obstacle to the world market. The distinct feature of the ship registration in PRC consists in existence of three different registration systems: in the Mainland PRC, in Hong Kong, and in Macau. That basically creates parallel legal orders with different requirements. Furthermore, in the case of Hong Kong one faces even a different legal system based on Common law, which is applicable to the vessels registered. 


\section{Methodology}

Based on the analysis of the current legislation of the People's Republic of China and the special administrative regions of Hong Kong and Macao, the advantages and disadvantages of the current legal framework for the registration of maritime vessels in contemporary territory of China are outlined. The research was conducted using common scientific and special legal methods. In particular, the use of the dialectical method made it possible to determine the development of the legal basis of the procedures for registration of vessels in the mainland China and special administrative districts and the impact on it of objective historical and political factors. Using formal legal and comparative methods, the texts of legislation of the People's Republic of China and the special administrative regions of Hong Kong and Macau in the field of vessel registration have been investigated. And the methods of analysis, synthesis and conceptual forecasting helped in shaping directions of possible and desirable changes in the organizational and legal mechanism of registration of vessels in the territory of the PRC.

\section{International legal regulations of the state registration of vessels}

The key links in the complex system of international maritime navigation are the sea itself and the vessel as a man-made complex object and a source of high risk (both in terms of accident and sea pollution). While ship owners have primary responsibility for the safe operation of their ships and the safety and welfare of their crews, the flag State plays a critical role by ensuring that the owners of ships flying its flag act in accordance with their international obligations (Bateman, 2015, p. 43).

UNCLOS'82 in art. 94 states:

"1. Every State shall effectively exercise its jurisdiction and control in administrative, technical and social matters over ships flying its flag.

2. In particular every State shall:

(a) maintain a register of ships containing the names and particulars of ships flying its flag, except those which are excluded from generally accepted international regulations on account of their small size; and

(b) assume jurisdiction under its internal law over each ship flying its flag and its master, officers and crew in respect of administrative, technical and social matters concerning the ship. 
3. Every State shall take such measures for ships flying its flag as are necessary to ensure safety at sea with regard, inter alia, to: (a) the construction, equipment and seaworthiness of ships; (b) the manning of ships, labour conditions and the training of crews, taking into account the applicable international instruments; (c) the use of signals, the maintenance of communications and the prevention of collisions...".

Vessel registration exists with varying degrees of differences in all countries of the world. It is regarded as a form of state supervision of vessels flying the national flag of the country. With the help of registration, the state controls the moment when the vessel has the right to sail under the national flag, compliance with national legislation on the alienation of vessels and their pledge, as well as legislation on the safety of navigation. Vessel registration allows the keeping of a fleet sailing under the national flag of the country, developing various programs and measures for the development or support of the national fleet. The second purpose of compulsory registration is to evaluate those qualities of the vessel that have an effect on the amount of profit and to transfer that estimate in the register ton.

Giving a vessel a nationality and the right to sail under the flag of the state concerned is a key point in its registration. Vessel registration is a legal act of recognition by a state of origin, restriction, transfer or termination of the rights to a vessel and is the only evidence of the existence of registered rights.

The process of vessel registration "presents opportunity for flag States to verify compliance with national and international laws... Most flag states discharge their responsibilities through national maritime administration that manages the national ship register and develops national legislation to fulfill the nation's responsibilities as a flag State" (Bateman, 2015, p. 47). Respectively, it is up to national administrative legislation and procedures to provide due compliance with international standards. And on the other hand, the process of vessels registration itself is bind with UNCLOS provisions. The issue is in the current of general UNCLOS approach to realization of States responsibilities, which is that "international rules and standards link states in ways and means of administering... and disseminate recommended and best practices" (Kormych, Averochkina, Gaverskyi, 2020).

State registration of vessels is also a means of determining the legal status of property, which, in accordance with the provisions of international 
agreements, has a public-law character and is an administrative-legal fact that produces legal consequences. Without official registration in any country, the vessel is only a floating object, the property whose legal status is determined by its location. But only from the moment of official registration and obtaining the right to sail under the flag of any country a floating object will become a vehicle, a vessel entitled to sail on the high seas. Thus, the legal regime of property and, in particular, the ownership of a vessel as a vehicle can only be certified upon (after) registration of the vessel in any country. The law governing the registration of the vessel, as well as the legal regime for the use of the property, including the certificate of ownership of the vessel, is the law of the country which has granted the vessel the right to sail under its flag.

The term "nationality" in the maritime law is applied to a vessel conditionally, that is, in a sense somewhat different from that applicable to the citizens. The "nationality" of a vessel is understood as its belonging ("legal subordination") to a particular state. That is, the nationality of the vessel determines the state to which the vessel is subject to the law.

Due to the fact that UNCLOS'82 failed to put in place "rigid" mechanisms for maintaining real communication between the ship and the state of registration, the practice of so-called "convenient" flags began to spread. It has become a negative phenomenon in modern international shipping and is shaking the foundations of maritime law laid down by UNCLOS'82. In order to correct it, the United Nations Convention on Conditions for Registration of Ships was adopted before the entry into force of UNCLOS'82 in 1986. The purpose of the Convention is defined as follows:

"For the purpose of ensuring or, as the case may be, strengthening the genuine link between a State and ships flying its flag, and in order to exercise effectively its jurisdiction and control over such ships with regard to identification and accountability of shipowners and operators as well as with regard to administrative, technical, economic and social matters, a flag State shall apply the provisions contained in this Convention".

This Convention represents the culmination of efforts to define the necessary elements for the registration of vessels in a national registry. Its provisions include references to the genuine link, ownership, management, registration, accountability and the role of the flag state. This 
article examines each issue separately and focuses on the most important elements of ship's registration: the concept of genuine link and beneficial ownership. The main reason behind the drive for the establishment of strict regulations on registration was the proliferation of open registries, their equation with substandard and hazardous conditions and efforts from developing countries to participate equally in the management of maritime transport (Kasoulides, 1989).

The main novelties of the 1986 Convention aimed at overcoming the practice of "convenient" flags are the norms of Art. 6, 8, 10 on identification and accountability, ownership of vessels and the flag state's role in managing the shipping companies. But significant requirements for entry into force, set out in Art. 19 of the Convention cannot yet be reached : ...

"1. This Convention shall enter into force 12 months after the date on which not less than 40 States, the combined tonnage of which amounts to at least 25 per cent of world tonnage, have become Contracting Parties to it in accordance with article 18. For the purpose of this article the tonnage shall be deemed to be that contained in annex III to this Convention.

2. For each State which becomes a Contracting Party to this Convention after the conditions for entry into force under paragraph 1 of this article have been met, the Convention shall enter into force for that State 12 months after that State has become a Contracting Party".

That is why the practice of "open", "convenient", etc. registers is still preserved and widely used in the field of international maritime navigation (by the way, since the beginning of the 20th century, when Panama started such practice). Many commercial ships are registered under a flag that does not match the nationality of the vessel owner. For example, at the beginning of 2019, one half of all ships owned by Japanese entities were registered in Panama; one fifth of the ships owned by Greek entities were registered in the Marshall Islands, and another fifth in Liberia. Panama (333 million dwt), Marshall Islands (246 million dwt) and Liberia (243 million dwt) were the leading flags of registration. Hong Kong SAR and Singapore followed in fourth and fifth place (Major flags of registration).

At the same time, open registries, like other registers, contain a wide variety of tonnage, of different ages and construction; some vessels are operated by large multinational corporations, like the major oil 
companies. Some of the most modern ships are being operated under open registers and the more responsible open register States have taken steps to exclude old and aging tonnage from their register. Panama requires vessels over 20 years of age to undergo a special inspection before the Permanent Certificate of Registry can be issued. Liberia generally requires that vessels seeking registration (or re-registration) are not more than 20 years old and Bahamas generally applies a 12 year age limit. All the major open registers are parties to the generally accepted international maritime safety conventions and the more responsible registries have a network of worldwide inspectors to ensure compliance (Rogers, 2010, p. 33).

With this respect PRC presents the exceptional example with the focus on registering vessels under its national flag. Due to UNCTAD data at the beginning of 2019 Chinese subjects owned 6125 commercial ships of $1000 \mathrm{gt}$ and above, and the 3987 of them were flying PRC flag, which constituted $65 \%$ of the whole Chinese commercial fleet. Besides, the 905 Chinese owned ships were registered in Hong Kong SAR, which in aggregate rise the share of ships under national flag up to rough $80 \%$ (Merchant fleet).

\section{Registration of vessels in the Mainland China}

The start of development of Chinese-flag merchant fleet can be traced back to early 1960. Before that time the P.R.C. owned ships often enough used a flag-of-convenient because of political reasons. Particularly, the P.R.C. at the beginning of 1960th owned a decent number of ships registered in Hong Kong, which flew the British flag (Muller, 2018). However, the course on enhancing the national flag fleet was taken in the 1963, when the Register of Shipping of PRC was established under control of the Ministry of Communications (Dicks, 1977, p. 257).

The 1983 Law "On the Safety of Maritime Transport" of the People's Republic of China establishes general rules for the inspection and registration of vessels, as well as some other aspects of maritime safety (navigation rules, rules for mooring and loading operations, ensuring the protection of the safety of the vessel, transportation of dangerous goods, etc.) (Lipin).

The most remarkable revision of PRC legislation on ship mortgages and registration was made at the beginning of 1990th, which was prompted by China's need to purchase more vessels and obtain shipping finance 
through finance structures such as equity, debt, or charters consistent with international standards (Chan, 1999, p. 423).

That new vessels registration "package" included the Regulations of the People's Republic of China on Ship Registration (Regulations governing the registration of ships, 2014), which was issued by the PRC State Council on June 2, 1994, Document No. 155 and entered into force on January 1, 1995 (hereafter - Registration Regulations), and the Interim Measures for Registration of Mortgage over Ships under Construction, issued by the PRC State Marine Safety Administration on June 9, 2009 (Notice of the Maritime Safety Administration of the People's Republic of China on Issuing the Interim Measures for the Registration of Mortgages over Ships under Construction, 2009).

Besides, in order to expand registered fleet tonnage and strengthen ship management, China began to introduce a special tax-free ship registration (STFSR) policy in July 2007. Under that policy international oceangoing ships of shipping enterprises with Chinese investment, in which the Chinese state or private capital accounts for no less than $50 \%$, which had already registered in other states could re-register under this new policy, and thereby enjoy the preferential government exemptions from import duties and value- added tax. The policy was in effect for more than eight years, culminating in complete failure in December 2015 (Jihong Chen, Kevin X. Li, Xiang Liu, Haobo Li, 2017, p. 22).

It should be noted that the PRC has traditionally adhered the closed register policy, which consist in the basic principle that Chinese vessel registration is not open to foreign owned or operated vessels (Zou, Liu, 2019, p. 17).

Furthermore, Article 4 of Registration Regulations additionally prohibits a dual ship nationality, stipulating that "A ship registered abroad shall not be granted Chinese nationality unless the former registration has been suspended or cancelled".

Besides, there additional demands for crew nationality of the vessels flying Chinese flag. In accordance to Article 7 of Registration Regulations, ships of Chinese nationality shall be manned by Chinese citizens. The recruiting of foreign seafarers can take place only in case of necessity and demands special permission of the competent authority of transport and communications under the State Council. Moreover, such foreign seafarers should hold the certificates if competency issued by the PRC authorities. 
The criteria for ships that are to be registered in Chinese Register are provided in the Atricle 1 of the Registration Regulations. The respective list includes:

(1) Ships owned by citizens of the People's Republic of China whose residences or principal places of business are located within the territory thereof;

(2) Ships owned by enterprises with legal person status established under the laws of the People's Republic of China and whose principal places of business are located within the territory thereof, provided that, where foreign investment is involved, the proportion of registered capital contributed by Chinese investors shall not be less than 50 per cent;

(3) Service ships of the government of the People's Republic of China and ships owned by institutions with legal person status; and

(4) Other ships whose registration is considered necessary by the competent authority of harbour superintendency of the People's Republic of China.

There are certain exceptions for above mentioned rule, primary concerning bareboat chartering of vessels to Chinese entities. Due to the Article 25 of Registration Regulations, the owner or demise charterer must register a demise charter in the event that:

a) the Chinese-flagged ship is demise chartered to a Chinese company;

b) a Chinese company demise chartered-in to a foreign-flagged ship; or

c) a Chinese-flagged ship is demise chartered-out to a foreign company.

To register the demise charter, the owner and demise charterer must submit the original demise charter party, the certificate of nationality and certificate of ownership in the case of a charter-in of a foreign-flagged ship, class technical certificates and termination or cancellation of the nationality certificate issued by the previous port of registry (Poynder, Cao, 2019, p. 148).

Besides, there are a few types of ships, including military ships, fishery ships and sports craft, that registration process is subject to different regulations.

For example, the registration of fishing vessels is governed by the Measures of the People's Republic of China on the Registration of Fishing Vessels, originally issued by the Ministry of Agriculture of PRC in 2012 and amended in 2019 (Order on Measures of the People's Republic of China on the Registration of Fishing Vessels, 2019). It should be noted, that PRC legislation has adopted broad understanding of the term "fishing 
vessel", which includes "all vessels associated with shipping activities [and] also covers vessels for fisheries enforcement" (Xue, 2005, p. 142).

All physical persons, legal corporates or legal entities with residence or principal place of business in China may apply to register a ship in accordance with the law and rules. A foreign vessel demised-chartered by a Chinese corporate legal person can be registered under the PRC flag provisionally, but the original registration port or country shall also be listed in the registration certificate. A vessel under construction in China may be registered under the PRC flag and granted with a certificate of temporary Chinese nationality after registration. In addition, according to Measures on the Registration of Ships 2016, a vessel owned by corporate legal persons incorporated in China only for the internal use, or a vessel owned or demise-chartered by corporate legal persons incorporated in the pilot free trade zone of China that engages only in the international trade, can be registered under the PRC flag even if the share of investment of the foreign investors exceeds 50 per cent (Chenbiao, 2019).

A shipowner applying for registration of the ownership of a ship shall produce to the ship registration authority at the port of registry the documents adequately evidencing his legitimate identification, and submit the originals and copies of the documents evidencing the procurement of his ownership over the ship and the technical information thereof. For the registration of ownership of a ship purchased, the following documents shall be submitted:

(1) Seller's invoice or sales contract and delivery document;

(2) Document issued by the ship registration authority at the original port of registry certifying the deletion of the original ownership registration; and

(3) Document evidencing that the ship is not under mortgage or that the mortgagees agree to the transfer of the mortgaged ship.

For the registration of ownership of a newly built ship, the contract of ship construction and the delivery document shall be submitted. For the registration of ownership of a ship under construction, the contract of ship construction shall be submitted. For the registration of ownership of a ship built by oneself for one's own use, a document evidencing the procurement of ownership shall be submitted.

For the registration of ownership of a ship procured through heritage, donation, auction under legal process, or court judgement, a document with appropriate legal effect evidencing the ship's ownership shall be submitted. 
In accordance with Article 14 of Registration Regulations, the certificate of registration of ship's ownership in the case of compliance with registration rules and requirements is to be issued within 7 days after the date of receipt of the application, whereupon an official registration number shall be granted to the registered ship and the following particulars shall be recorded in the register of ships: (1) Ship's name and its call sign; (2) Port of registry, official registration number and identification mark of the ship; (3) Name and address of the shipowner and name of his legal representative; (4) Way in which the ship's ownership was procured and the date of procurement; (5) Date on which the ship's ownership was registered; (6) Name of ship builder, and time and place of building; (7) Value of the ship, material of ship's hull and ship's main technical information; (8) Original name and port of registry of the ship and the date of deletion or suspension of its original registration; (9) Information about joint ownership if the ship is owned by two or more owners; (10) Name and address of bareboat charterer or ship operator, and name of his legal representative, in case the shipowner is not the one who operates or actually controls the ship; and (11) Information about the establishment of mortgage, if any.

The ship registration authority shall inform the shipowner in writing of any non-compliance of his application with Registration Regulations within 7 days after the date of receipt of the application.

The registration of mortgages is governed by the Articles 23-24 of Registration Regulations. To register a mortgage, the mortgagor and the mortgagee must apply together to the registry with a certificate of ownership or shipbuilding contract and the mortgage agreement. If the application is in order, the registry will record the mortgage in the ship's certificates and ownership certificate, and will issue a certificate of mortgage to the mortgagee within seven days.

As it was mentioned, such strict requirements are the peculiarity of the legislation of Mainland China. Special administrative districts have broad autonomy and the characteristics of typical offshore zones.

Besides, grounding at the experience of non-successful implementing STFSR, in 2013 and 2015, during the official planning of Shanghai and Tianjin Free Trade Zones (FTZs), the Chinese government made it clear that China would test its international ship registry (CISR) system in the above-mentioned free trade zones (Jihong Chen, Kevin X. Li, Xiang Liu, Haobo Li, 2017, p. 26). 
In 2017 three FTZ in east China's Fujian Province have received approval for international ship registration services, according to Fujian Marine Safety Administration under the Ministry of Transport Saturday. Following the approvals issued to Fuzhou, Xiamen and Pingtan ports there are now eight FTZs capable of registering vessel ownership. The other ports are in Shanghai, Tianjin and Guangdong. More than 663,000 ships sailed from or arrived at Fujian in 2016, of which 42,000 were international. The move will attract more ships to be registered at Fujian FTZs, conducive to expanding the ship financing market and speeding up the development of ship service industry in Fujian (Three ports to launch shipping registration in E-China).

\section{Legislation of the special administrative regions of Hong Kong and Macau on the registration of maritime vessels}

Hong Kong (Xianggang) is one of the two special administrative regions of the PRC, which for 155 years (from 1842 until its return to the jurisdiction of China in 1997) was in colonial dependence on Great Britain. Hong Kong is one of the leading business centers of Asia and the whole world, and world ratings for more than twenty years have repeatedly awarded the autonomy the first place in the list of the freest economies in the world (Xianggang lianren quanqiu zui ziyou jingjiti Zhongguo pai 111 er; Yanlun, 2017). Until July 2047, a unique legal system will operate in Hong Kong, including English law and the law of the Qing Empire, as well as Hong Kong's own legislation and some of the laws of the PRC, which are valid in the territory of this administrative region. Hong Kong has a Common law legal system, formed during the period of British rule.

After reunification Hong Kong maintained its own shipping register, which current version was established in December 1990 under the Merchant Shipping Registration Ordinance that set out the procedure for registering and deleting ships in Hong Kong, creating and discharging mortgages on such ships and other related matters (Chan, 1999, p. 407).

The Basic Law of the Hong Kong Special Administrative Region of the People's Republic of China includes specific Chapter V Section 3 dealing with shipping issues, and provides the basic rules determining legal statues of Hong Kong ship register and other shipping-related activities:

\section{"Article 124}

The Hong Kong Special Administrative Region shall maintain Hong Kong 's previous systems of shipping management and shipping 
regulation, including the system for regulating conditions of seamen. The Government of the Hong Kong Special Administrative Region shall, on its own, define its specific functions and responsibilities in respect of shipping.

\section{Article 125}

The Hong Kong Special Administrative Region shall be authorized by the Central People's Government to continue to maintain a shipping register and issue related certificates under its legislation, using the name "Hong Kong, China".

\section{Article 126}

With the exception of foreign warships, access for which requires the special permission of the Central People's Government, ships shall enjoy access to the ports of the Hong Kong Special Administrative Region in accordance with the laws of the Region.

\section{Article 127}

Private shipping businesses and shipping-related businesses and private container terminals in the Hong Kong Special Administrative Region may continue to operate freely".

The major change for ships registered in Hong Kong SAR was that those ships changed their nationality from British to Chinese. Thus, following 1 July 1997, the flag of PRC is now to be flown above the flag of HKSAR (Chan, 1999, p. 426).

Hong Kong has recently become a new hot spot for ship registration. Ships registered in Hong Kong are taxed at a lower rate than those registered in Mainland China. Also, because Hong Kong places emphasis on flag State control (FSC) inspections and ships registered in the region are unlikely to be the objects of port State control (PSC). Since seafarers' rights and environmental affairs are of major concern to the international community and because Hong Kong is a free port and the gateway to Mainland China, it is considered to be a better option than the Mainland for registry of Chinese funded ships (Liying, 2010).

The autonomy of the Hong Kong Shipping Register is well enshrined in the Basic Law. It provides the constitutional rights and legal basis for Hong Kong to continue to maintain a shipping register and to issue related certificates under its own legislation under the name "Hong Kong, China". The Merchant Shipping (Registration) Ordinance governs vessel registration. The register is run by the Marine Department of the Hong Kong Special Administrative Region Government and is separate from 
the Chinese Register. One unique feature of the Hong Kong Register is the requirement to hoist two flags at the stern of a Hong Kong ship, that is, the national flag of the People's Republic of China and the regional flag of the Hong Kong Special Administrative Region. A number of measures have been implemented since 1 April 1999 to make the Hong Kong Register even more competitive, user friendly and efficient. These measures are aimed to further improve the Register's quality at a reduced cost. The measures include reduction of fees; streamlining of procedures for ship registration, seafarers' licensing and employment and discharge of seafarers; and 365 days plus 24 hours services. In addition, a flag-state quality control (FSQC) system has been introduced to ensure highest safety standards and full compliance with international conventions by all Hong Kong registered ships in a cost-effective manner (Hong Kong. About the Flag).

As at January 2019, there were more than 2,623 vessels on the Hong Kong Shipping Register, totaling more than 125.4 million gross tonnage and 9 per cent of the world's merchant fleet, making it the fourth-largest register after Panama, Liberia and the Marshall Islands. In addition, Hong Kong remains a major center for ship management, finance, insurance, logistics, terminal operations, maritime arbitration and legal services (Hui, Chung, 2019, p. 222).

There are two types of persons who are eligible to file a registration documents. A Qualified Person must be one of the followings: (a) an individual who holds a valid Hong Kong Identity Card and who is ordinarily resident in Hong Kong; or (b) a body corporate incorporated in Hong Kong; or (c) a company registered with the Hong Kong Companies Registry as an Non-Hong Kong company. In addition to the owner or the demise charterer, a local "Representative Person" shall also be appointed. A Representative Person must be: (a) a qualified person and the owner or part owner of the ship; or (b) a body corporate incorporated in Hong Kong engaging in the business of ship management, or acting as agent for ships (Hong Kong shipping registry. Ship registration guidelines, 2019, p. 4).

In accordance to Paragraph 11 (1) of the Merchant Shipping (Registration) Ordinance (An Ordinance to provide for the registration of ships in Hong Kong and for related matters, 1990) a ship to be registrable in Hong Kong SAR should comply with following requirements:

(a) a majority interest in the ship is owned by one or more qualified persons; or 
(b) the ship is operated under a demise charter by a body corporate being a qualified person (whether or not a majority interest in the ship is owned by one or more qualified persons), and a representative person is appointed in relation to the ship.

Respectively, the application for registrations should be made by made by the person or persons applying to be registered as owner, or in case of operation under demise charter by both the demise charterer and the owner (Paragraph 19(1), (2)).

The application itself should include a series of declarations made by or on behalf of the owners or demise charterers. The respective list typically include the information of owner or demise charterer, information of ownership or charter rights towards the vessel in question and the information of the vessel itself (Paragraph 20).

For example, the information of ownership includes:

- a statement of the number of shares in, or the fraction or percentage of, the ship in respect of which the legal title will be vested in the declarant;

- a statement that to the best of the declarant's knowledge and belief a majority interest in the ship will upon registration be owned by one or more qualified persons.

In the case of demise chartered vessel the respective information covers:

- a statement that the body corporate has entered into a demise charterparty in respect of the ship with the owner of the ship;

- a statement that pursuant to the terms of the demise charter-party the body corporate is able to register the ship in its name as the demise charterer.

Finally, the information of the vessel should include:

- a statement that the general description of the ship contained in the application is correct;

- a statement that the ship is not registered in any place outside Hong Kong or, if it is so registered, that the declarant will secure deletion of the ship from the register in every such place.

Also ship registration can be on full registration or provisional registration. However, provisional registration is not a prerequisite for full registration. Provisional registry should be appropriate when the original title documents cannot be produced at the time of registration. Certificate of Registry (with no expiry date) will be issued to a ship on full registration upon successful delivery of the ship and submission of the original title document. Certificate of Provisional Registry with one month validity will 
be issued to a ship upon successful delivery of the ship and submission of the photocopy/scanned copy of the title document. Original title document must be presented to the Registry within the validity period in order to change the ship to full registration (Hong Kong shipping registry. Ship registration guidelines, 2019, p. 3).

The pre-registration quality control system (PRQC) was introduced in 2004 to ensure ships joining the Register comply with applicable safety and pollution prevention standards of the relevant international conventions. Upon receiving an application to join the Register, the Marine Department will assess the conditions of the ship and determine whether a PRQC inspection is required. If the condition of a ship is found unacceptable, registration will be refused (Hui, Chung, 2019, p. 238). At the web-site of the Marine department of the Hong Kong Special Administrative Region notes: "The Pre-Registration Quality Control (PRQC) System ensures ships joining the Hong Kong Shipping Register are of good quality. MD will, on receiving a ship registration application, carry out a desk top evaluation of the quality level of the ship taking into account various quality factors including but not limited to the ship age, ship type, number of PSC detention, number of PSC deficiencies, existing flag, existing classification society, the ship's survey records and accident records to consider if the ship warrants an onboard PRQC Assessment, an onboard inspection to be carried out by one of the classification societies recognized by MD as RO" (Quality Assurance Systems. Flag State Quality Control System).

Some authors strongly recommend that China reorient its maritime policy by incorporating Hong Kong as its second ship register to provide a competitive operational environment for shipping companies and thereby foster a maritime cluster (Yin, Fan, Li, 2018).

Macau (Aomin) is an international free port, which is one of the most densely populated areas in the world. Thanks to its developed light industry, tourism, hotel industry and casino, Macau is one of the most prosperous regions of the world (Sjuj, 2018, p. 21). The Macau legal system is formed by the laws of Portugal, the local laws of Macau and the laws developed by Portugal for Macau. Macau is subject to the five codes of Portugal: Civil, Criminal, Commercial, Criminal Procedure and Civil Procedure. The Macau legal system has the obvious characteristics of Portuguese law, as reflected in the legal sources, legal structure, judicial system and legal operations. Since Portuguese law belongs to the continental legal system (it is based on statutory laws, not judicial 
precedents), Macau law is much closer to the law of mainland China than Hong Kong (Troshhinskij, 2015, p. 102).

The Basic Law of the Macao Special Administrative Region of the People's Republic of China 1993 provides:

\section{"Article 116}

The Macao Special Administrative Region shall maintain and improve Macao's previous systems of shipping management and shipping regulation, and make shipping policy on its own.

The Macao Special Administrative Region shall be authorized by the Central People's Government to maintain a shipping register and issue related certificates under its legislation, using the name "Macao, China".

With the exception of foreign warships, access for which requires the special permission of the Central People's Government, ships shall enjoy access to the ports of the Macao Special Administrative Region in accordance with the laws of the Region.

Private shipping businesses and shipping-related businesses and terminals in the Macao Special Administrative Region may continue to operate freely".

The maritime registration for ships is provided for vessels intending to be registered in the Macao Special Administrative Region. According to the "Regulations on Maritime Activities" approved by decree-law no. 90/99/M (Maritime Registration for Ships), vessels carrying out the activities which determine their category, must be registered in the maritime registration of the Marine and Water Bureau.

Applications can be made by applicant or his/her legal representative, or a lawyer or legal agent from a law firm in Macao. The following documents should be submitted in person. Completed application form (the form can be obtained from the location for application):

- Application form for maritime registration/cancellation/change or revision/renewal/replacement for ships (format I 1/DET); (applicable to all vessels except pleasure boats);

- Application form for maritime registration/deletion of ship's log/ change or revision of ship's log/renewal/replacement for pleasure boats (format I 1A/DET); (applicable to pleasure boats);

- Certified copy of identification document;

- Photocopy of duly updated business registration certificate, issued by the Commerce and Movable Property Registry, if the applicant is 
a corporate (original copy to be presented for verification) (The applicant can request the Marine and Water Bureau to access the business registration certificate via the joint network established by the Legal Affairs Bureau in order to be exempted from submitting the concerned document);

- Certificate of acquisition of ship (original copy to be presented for verification);

- Document certifying the number of construction licence and the date (if applicable);

- Tonnage certificate;

- Documents certifying radio marker (call signs) (if applicable);

- Certificate of registration inspection;

- Supporting documents of import duties and other customs fees payment, if it is an entering ship;

- Certificate showing the cancellation of previous registration and navigation permit, if it is a non-Macao registered ship (to be submitted after the ship has passed the inspection and can be submitted as a supplementary document);

- Photocopy of proof of address (such as electricity or water bill).

Documents required to be processed/applied in advance:

- Notarized documents signed by the applicant (if applicable);

- Certified copy of identification document;

- Payment of stamp duty;

- Duly updated business registration certificate, issued by the Commerce and Movable Property Registry, if the applicant is a corporate (The applicant can request the Marine and Water Bureau to access the business registration certificate via the joint network established by the Legal Affairs Bureau in order to be exempted from submitting the concerned document);

- Proof of acquisition of ship;

- Document certifying the number of construction licence and the date (if applicable);

- Documents certifying radio marker (call signs) (if applicable);

- Supporting documents of import duties and other customs fees payment, if it is an entering ship;

- Pursuant to the Notary Code, documents issued outside of Macao should be translated (if necessary).

Signature of the applicant should be notarised, except when the applicant submits the application form in person and proves his/her identity with an 
identification document. Such procedure must be done while submitting the application.

If the application form is submitted by a lawyer or legal agent from a law firm in Macao, notarised signature is exempted.

Documents issued outside of Macao SAR are accepted according to the Civil Law; when necessary, persons of interest should submit translated copies of those, in accordance with the Code of Notaries (Application for Maritime Registration for Ships).

\section{Conclusions}

Thus, if the law of mainland China contains a clear indication of the citizenship of a person who has expressed a desire to register a ship in that country, then the legislation of the special administrative districts does not contain such a rule. This is a consequence of the legal tradition in these territories of the western and somewhat more democratic than in mainland China. It is also facilitated by the right to self-identify and regulate most areas of domestic policy, which include shipping. In addition, trends aimed at attracting more vessels under their flag and therefore investments are prevalent in these territories. As directions for possible changes in the organizational and legal mechanism of registration of the vessels in the $\mathrm{PRC}$, the support should be given to the incorporation of registers of special administrative districts into the system of registration of the vessels of the PRC in order to create the most powerful maritime cluster in the world.

\section{REFERENCES}

An Ordinance to provide for the registration of ships in Hong Kong and for related matters, 1990 (the Government of the Hong Kong Special Administrative Region). Retrieved March 19, 2020, from: https://www.elegislation.gov.hk/hk/cap415?xpid=ID_1438403 176095_001

Application for Maritime Registration for Ships. Macao SAR Government Portal. Retrieved March 15, 2020, from: https://www.gov.mo/en/services/ps-1811/ps-1811a/

Basic Law of the Hong Kong Special Administrative Region of the People's Republic of China, 1990 (Seventh National People's Congress). Retrieved March 15, 2020, from: https://www.basiclaw.gov.hk/en/basiclawtext/images/basiclaw_full_text_en.pdf

Bateman, S. (2015). The Role of Flag States. In: Robin Warner \& Stuart Kaye (Ed.). Routledge Handbook of Maritime Regulation and Enforcement. London. New York. Routledge. 
Chan, F. (1999). Recent Reforms and Developments of Mainland Chinese and Hong Kong Maritime Law. The New Legal Order in Hong Kong. Ed. by Richard Wacks. Hong Kong. Hong Kong University Press.

Chenbiao, L. (2019). Shipping. Getting the deal through. Retrieved March 15, 2020, from: https://gettingthedealthrough.com/area/37/jurisdiction/27/shipping-china/

China-owned fleet becomes world's second largest. Hellenic Shipping News WorldWide. Retrieved March 2, 2020, from: https://www.hellenicshippingnews.com/ china-owned-fleet-becomes-worlds-second-largest/

Convention on the Law of the Sea, 1982 (United Nations). The official website of UN. Retrieved March, 5, 2020, from: http://www.un.org/depts/los/convention_agreements/ texts/unclos/unclos_e.pdf

Convention on Conditions for Registration of Ships, 1986 (United Nations). UN Treaty Collection. Retrieved March, 5, 2020, from: https://treaties.un.org/doc/ Treaties/1986/02/19860207\%2008-58\%20AM/Ch_XII_07p.pdf

Deadweight tonnage of world merchant fleets by operator domicile as of January 1, 2019. Statista.com. Retrieved March 2, 2020, from: https://www.statista.com/statistics/263889/ dwt-of-merchant-fleets-worldwide-by-country-of-domicile/

Dicks, A.R. (1977). Some Aspects of Maritime Law and Practice. Law and Politics of China Foreign Trade. Ed. by Li Victor H. Hong Kong. University of Washington Press.

Hong Kong. About the Flag. Official Guide to Ship \& Yacht Registries. Retrieved March 15, 2020, from: https://www.guidetoshipregistries.com/shipregistries-country/hong-kong

Hong Kong shipping registry. Ship registration guidelines, 2019 (Marine department Hong Kong Special Administrative Region). Retrieved March 19, 2020, from: https://www.mardep.gov.hk/en/pub_services/pdf/sr_guide.pdf

Hui, N., Chung, W. (2019). Hong Kong. In: Eddings, G., Chamberlain, A., Colaço, H. (eds.) (2019). The Shipping Law Review. Sixth Edition. Law Business Research Ltd, London. P. 222-244. Retrieved March 19, 2020, from: https://thelawreviews.co.uk//digital assets/2a4a5f50-13ae-4331-b298-e160babef560/The-Shipping-Law-Review---Ed-6.pdf

Jihong Chen, Kevin X. Li, Xiang Liu, Haobo Li (2017). The development of ship registration policy in China: Response to flags of convenience. Marine Policy, 83, 22-28. https://doi.org/10.1016/j.marpol.2017.05.020

Kasoulides, G.C. (1989). The 1986 United Nations convention on the conditions for registration of vessels and the question of open registry. Ocean Development \& International Law, 20:6, 543-576. https://doi.org/10.1080/00908328909545915

Kormych, B., Averochkina, T. \& Gaverskyi, V. (2020). The public administration of territorial seas: Ukrainian case. Int Environ Agreements. https://doi.org/10.1007/s10784-020-09473-9

Lipin, C. Specifika nacional'nogo zakonodatel'stva KNR po obespecheniju bezopasnosti morskih perevozok [The specifics of the national legislation of China on ensuring the shipping safety]. Mezhdunarodnyj pravovoj kur'er. [International Legal Courier]. 
Retrieved March 15, 2020, from: http://inter-legal.ru/specifika-nacionalnogo-zakonodatelstva-knr-po-obespecheniyu-bezopasnosti-morskix-perevozok [in Russian].

Liying, Z. (2010). A Comparative Study of 'Hong Kong Flag' Ship Registration. Asia Pacific Law Review, 18:2, 197-211. https://doi.org/10.1080/10192557.2010.11788232

Major flags of registration. The UNCTAD Handbook of Statistics 2019. Retrieved March 13, 2020, from: https://stats.unctad.org/handbook/MaritimeTransport/MerchantFleet.html

Maritime Registration for Ships. Macao SAR Government Portal. Retrieved March 15, 2020, from: https://www.gov.mo/en/services/ps-1811/

Merchant fleet. The UNCTAD Handbook of Statistics 2019. Retrieved March 13, 2020, from: https://stats.unctad.org/handbook/MaritimeTransport/MerchantFleet.html

Muller, D.G. Jr. (2018). China as a Maritime Power. New York. Routledge.

Notice of the Maritime Safety Administration of the People's Republic of China on Issuing the Interim Measures for the Registration of Mortgages over Ships under Construction, 2009 (Maritime Safety Administration of the People's Republic of China). Pkulaw.com. Retrieved March 15, 2020, from: http://en.pkulaw.cn/display.aspx?cgid=118351\&lib=law

Order on Measures of the People's Republic of China on the Registration of Fishing Vessels, 2019 (Ministry of Agriculture and Rural Affairs of the People's Republic of China). Pkulaw.com. Retrieved March 15, 2020, from: http://en.pkulaw.cn/display. aspx?cgid=bfbb20196731 eec5bdfb\&lib=law

Poynder, N., Cao, J. (2019). China. In: Eddings, G., Chamberlain, A., Colaço, H. (eds.) (2019). The Shipping Law Review. Sixth Edition. Law Business Research Ltd, London. P. 139-152. Retrieved March 15, 2020, from: https://thelawreviews.co.uk//digital_ assets/2a4a5f50-13ae-4331-b298-e160babef560/The-Shipping-Law-Review---Ed-6.pdf

Quality Assurance Systems. Flag State Quality Control System. Web-site of the Marine department of the Hong Kong Special Administrative Region. Retrieved March 19, 2020, from: https://www.mardep.gov.hk/en/pub_services/qas.html

Regulations governing the registration of ships, 2014 (State Council). Pkulaw. com. Retrieved March 15, 2020, from: http://en.pkulaw.cn/display.aspx?cgid= 725 bd23223ea3620bdfb\&lib=law

Rogers, R. (2010). Ship registration: a critical analysis. World Maritime University Dissertations. 447. Retrieved March 13, 2020, from: http:/commons.wmu.se/ all_dissertations $/ 447$

Sjuj, L. (2018). Pravo VTO v pravovoj sisteme Makao [WTO law in the legal system Macao]. Jelektronnoe prilozhenie $k$ Rossijskomu juridicheskomu zhurnalu. [Electronic supplement to the Russian Juridical Journal], 4, 21-25. Retrieved March 19, 2020, from: https://cyberleninka.ru/article/n/pravo-vto-v-pravovoy-sisteme-makao [in Russian].

The Basic Law of the Macao Special Administrative Region of the People's Republic of China, 1993 (the Eighth National People's Congress). China.org.cn. Retrieved March 15, 
2020, from: http:/www.china.org.cn/china/LegislationsForm2001-2010/2011-02/12/ content_21907286.htm

Three ports to launch shipping registration in E-China. Xinhua.net. Retrieved March 17, 2020, from: http:/www.xinhuanet.com//english/2017-04/01/c_136176660.htm

Troshhinskij, P.V. (2015). Pravovaja sistema Kitajskoj Narodnoj Respubliki: stanovlenie, razvitie i harakternye osobennosti [Legal system of the People's Republic of China: formation, development and peculiarities]. Vestnik universiteta im. O. E. Kutafina (MGJuA). [Courier of the Kutafin Moscow State Law University (MSAL)], 5, 99-117. Retrieved March 15, 2020, from: https://cyberleninka.ru/article/n/pravovaya-sistema-kitayskoy-narodnoy-respubliki-stanovlenie-razvitie-i-harakternye-osobennosti/viewer [in Russian].

Xianggang lianren quanqiu zui ziyou jingjiti Zhongguo pai 111 er. Dongwang. 16.02.2017. Retrieved March 19, 2020, from: http://hk.on.cc/hk/bkn/cnt/news/20170216/bkn20170216092112749-0216_00822_001.html [in Chinese].

Xue, G. (2005). China and International Fisheries Law and Policy. Leiden. Martinus Nijhoff Publishers.

Yanlun, Z. (2017). Xianggang chanlian quanqiu zui ziyou jingji Xinjiapo paiming di er. Huanqiuwang. Retrieved March 20, 2020, from: http://world.huanqiu.com/ exclusive/2017-09/11297239.html [in Chinese].

Zou K., Liu, H. (2019). Regulation on Navigation of Foreign Vessels: China's Practice. Regulation on Navigation of Foreign Vessels: Asia-Pacific State Practice. Ed. by McDorman, T.L., Zou, K., Lee, S. Leiden-Boston: Brill.

\footnotetext{
АНОТАЦІЯ

Шуйбао Ч. Реєстрація морських суден у КНР: різноманіття правових режимів. - Статмя.

Статтю сфокусовано на визначенні механізму реєстрації морських суден у КНР. Базисом дослідження обрано міжнародно-правові норми у сфері реєстрації суден - конвенції ООН з морського права 1982 р. та про умови реєстрації суден 1986 р. Розглянуто законодавство материкового Китаю та спеціальних адміністративних районів Гонконг та Макао. Визначено процедури, що застосовуються для внесення суден до їх державних реєстрів. Окреслено позитивні та негативні тенденції розвитку реєстраційних механізмів та впроваджуваних новацій. Під час дослідження було застосовано низку загальнонаукових та спеціальних юридичних методів. Вони дозволили виробити авторське бачення можливих та бажаних змін в організаційно-правовому механізмі реєстрації суден на території КНР. Автор доходить до висновку про відмінності у процедурах реєстрації суден у материковому Китаї та у спеціальних адміністративних районах. Це є наслідком панівної на цих територіях західної та дещо більш демократичної, ніж у материковому Китаї, правової традиції. Також цьому сприяє надання адміністративним районам права на самостійне визначення та регулювання більшості сфер внутрішньої політики, до яких належить й судноплавна. У якості
} 
напрямів можливих змін в організаційно-правовому механізмі реєстрації суден на території КНР підтримано пропозиції щодо інкорпорації реєстрів спеціальних адміністративних районів у систему реєстрації морських суден КНР з метою створення найпотужнішого морського кластеру у світі.

Ключові слова: реєстрація суден, міжнародне судноплавство, морська політика, Китай, Спеціальний адміністративний район Гонконг КНР, Спеціальний адміністративний район Макао КНР.

\section{АННОТАЦИЯ}

Шуйбао Ч. Регистрация морских судов в КНР: разнообразие правовых режимов. - Статья.

Статья сфокусирована на определении механизма регистрации морских судов в КНР. Базисом исследования стали международно-правовые нормы в сфере регистрации судов - конвенции ООН по морскому праву 1982 г. и об условиях регистрации судов 1986 г. Рассмотрено законодательство материкового Китая и специальных административных районов Гонконг и Макао. Определены процедуры, применяемые для внесения судов в их государственные реестры. Очерчены позитивные и негативные тенденции развития регистрационных механизмов и внедряемых новаций. В ходе исследования был применен ряд общенаучных и специально-юридических методов. Они позволили выработать авторское видение возможных и желательных изменений в организационно-правовом механизме регистрации судов на территории КНР. Автор приходит к выводу о различиях в процедурах регистрации судов в материковом Китае и в специальных административных районах. Это стало следствием господствующей на этих территориях западной и несколько более демократичной, чем в материковом Китае, правовой традиции. Также этому способствует предоставление административным районам права на самостоятельное определение и регулирование большинства сфер внутренней политики, к которым относится и судоходная. В качестве направлений возможных изменений в организационно-правовом механизме регистрации судов на территории КНР поддержаны предложения по инкорпорации реестров специальных административных районов в систему регистрации морских судов КНР с целью создания самого мощного морского кластера в мире.

Ключевые слова: регистрация судов, международное судоходство, морская политика, Китай, Специальный административный район Гонконг КНР, Специальный административный район Макао КНР. 